\title{
Identification of prostatic-secreted proteins in mice by mass spectrometric analysis and evaluation of lobe-specific and androgen-dependent mRNA expression
}

\author{
Nariaki Fujimoto, Yukimi Akimoto ${ }^{1}$, Tomoharu Suzuki ${ }^{2}$, Shigeyuki Kitamura ${ }^{2}$ and Shigeru Ohta $^{2}$ \\ Department of Developmental Biology, Research Institute for Radiation Biology and Medicine, Hiroshima University, 1-2-3 Kasumi, Minami-ku, Hiroshima \\ 734-8553, Japan \\ ${ }^{1}$ Department of Radiation Responses, Research Institute for Radiation Biology and Medicine, Hiroshima University, 1-2-3 Kasumi, Minami-ku, Hiroshima \\ 734-8553, Japan \\ ${ }^{2}$ Department of Xenobiotic Metabolism and Molecular Toxicology, Institute of Pharmaceutical Sciences, Hiroshima University School of Medicine, Kasumi \\ 1-2-3, Minami-ku, Hiroshima 734-8551, Japan \\ (Requests for offprints should be addressed to N Fujimoto; Email: nfjm@hiroshima-u.ac.jp)
}

\begin{abstract}
Rats and guinea pigs have frequently been used to study the development of the prostate and the mechanism of androgen action, but the mouse prostate has also become an attractive model for prostate research, because an enormous range of genetically altered mice is now available. However, the secretion of proteins in the mouse prostate has not yet been thoroughly investigated. In the present study, major secreted proteins from the ventral prostate $(\mathrm{VP})$, dorsolateral prostate (DLP), and anterior prostate (AP) of mice were identified by means of $2 \mathrm{D}$-gel electrophoresis followed by MALDI-TOF mass spectrometric analysis. A quantitative reverse transcriptase-PCR method was further employed to examine the androgen-dependent transcriptional regulation of the identified proteins. Proteome analysis revealed that the VP secretes spermine-binding protein, serine protease inhibitor
\end{abstract}

Kazal type-3, and a $91 \mathrm{kDa}$ hypothetical scavenger receptor (AK035662). DLP and AP secrete a protein similar to immunoglobulin-binding protein, immunoglobulin-binding protein-like protein, and one of the experimental autoimmune prostatitis antigen proteins (EAPA2). Peroxiredoxin-6, glucoseregulated protein 78 , zinc- $\alpha 2$-glycoprotein, and phospholipase $\mathrm{C} \alpha$ are also secreted. Castration of animals led to a decrease in the mRNAs of these secreted proteins, although the extents of changes varied greatly among different lobes. We present here an outlined view of mouse prostate secretion, which should contribute to an understanding of the biological functions of the prostate gland, as well as the androgen dependency of prostate secretion.

Journal of Endocrinology (2006) 190, 793-803

\section{Introduction}

Rat models have been widely used to study prostate morphology, development, and pathology, as well as androgen-regulated gene expression, in order to understand the basic functions and pathology of this male accessory sex gland (Cunha et al. 1987). Mice have generally not been used because the small size of the gland makes morphological studies difficult, and because the mouse prostate is less susceptible to carcinogenesis (Shirai et al. 2000). Recently, however, a huge range of transgenic and knockout mice has become available with considerable potential for studies of the prostate (Abate-Shen \& Shen 2002, Klein 2005). Transgenic adenocarcinoma of the mouse prostate (TRAMP) mice has been used to study the progression and chemoprevention of prostate cancer (Greenberg et al. 1995). Prolactin transgenic mice have been used to investigate the effect of prolactin on prostate growth (Wennbo et al. 1997). Estrogen receptor knockout mice ( $\alpha$ ERKO and $\beta E R K O$ ) have been used to examine the role of estrogen in prostate development (Weihua et al. 2001, Omoto et al. 2005). Aromatase knockout, prolactin receptor knockout, and conditional deletion of $\mathrm{Rb}$ mice have been used to study the involvement of those genes in prostate carcinogenesis (McPherson et al. 2001, Robertson et al. 2003, Maddison et al. 2004). However, despite these recent developments, the basic biological function of the prostate, prostatic secretion, is still poorly understood in the mouse. Identification of the secreted proteins will be helpful in understanding prostate development and pathology.

The rodent prostate consists of the ventral prostate (VP), lateral prostate (LP), dorsal prostate (DP), and anterior prostate (AP or coagulating gland). It is well known that rat prostatic secretory proteins, such as prostatein and cystatin-related protein, are mainly produced in the VP, and other proteins, such as prostatic secretory protein of 94 aa (PSP94), probasin, 
and seminal vesicle secretion 2 (SVS2) are abundant in the LP and DP (Cunha et al. 1987). An early study revealed that spermine-binding protein (SBP) and serine protease inhibitor Kazal type-3 (SPI-KT3) are abundant in the mouse VP (Mills et al. 1987a, 1987b). Proteins secreted from the dorso-lateral prostate (DLP) and AP have not yet been identified, although Cunha's group developed a specific polyclonal antibody for major DLP protein(s) to be used as a differentiation marker (Donjacour et al. 1990).

In the present study, the major proteins secreted from the VP, DLP, and AP were identified by means of 2D-gel electrophoresis followed by MALDI-TOF mass spectrometric analysis. Further, a quantitative reverse transcriptase (RT)-PCR method was employed to examine the androgen dependence of the transcriptional regulation of the secretory proteins.

\section{Materials and Methods}

\section{Animals}

Animal experiments were conducted in accordance with $A$ Guide for the Care and Use of Laboratory Animals of Hiroshima University. The male C57BL mice were purchased from Charles River Japan Co. (Kanagawa, Japan) and maintained with free access to basal diet and tap water. For proteome analysis, three of the 11-week-old mice were killed under ether anesthesia and the prostate and seminal vesicle (SV) were carefully dissected out. In addition, four animals were used for evaluating the sample preparation method. For the study of age-dependent mRNA expression, animals were killed at 1, 2, 4, 6, and 11 weeks (four animals per group), and each of the prostate lobes was dissected under a microscope and immediately fixed in RNA Later solution (Ambion, Inc., Austin, TX, USA). For the castration and hormone-replacement study, animals were divided into three groups, the castrated, castrated plus testosterone injected, and intact. Surgical castration was made at 10 weeks of age and animals were allowed to recover for 1 week. Testosterone propionate (Wako Junyaku KK, Osaka, Japan) was dissolved in the vehicle oil, Panacete 810 (Nippon Oils and Fats Co., Ltd, Tokyo, Japan), and the solution was administered i.p. at a dose of $5 \mathrm{mg} / \mathrm{kg}$ body weight. Animals were killed under ether anesthesia $24 \mathrm{~h}$ after testosterone injection, and the prostate lobes were collected for RNA extraction.

\section{Preparation of secretion samples}

Preparation of secretion samples was performed based on the previously reported method (Donjacour et al. 1990). Each dissected prostate lobe from an 11-week-old mouse was rinsed well in saline and placed on a $35 \mathrm{~mm}$ culture dish with $100 \mu \mathrm{l}$ saline containing 1\% protease inhibitor mixture (Sigma). Each lobe was cut into four or five pieces, left to stand for $5 \mathrm{~min}$, and transferred to a $1.5 \mathrm{ml}$ microcentrifuge tube. After centrifugation at $10000 \mathrm{~g}$ for $5 \mathrm{~min}$ at room temperature, the supernatant was collected as the secretion sample. The incubation time of $5 \mathrm{~min}$ was chosen because inner cellular contamination (glyceraldehyde-3-phosphate dehydrogenase; GAPDH) was confirmed to below by $5 \mathrm{~min}$ (Fig. 1). For the SV secretion sample, the content of the vesicle was collected and suspended in saline with protease inhibitors. The protein concentration of each sample solution was determined with a Protein Assay kit (Bio-Rad Lab.). For de-glycosidation, samples were incubated with PNGase F $(50 \mathrm{U} / \mu \mathrm{g}$ protein; New England Biolabs, Ipswich, MA, USA) at $37^{\circ} \mathrm{C}$ for $1.5 \mathrm{~h}$.

\section{Electrophoresis (1D and 2D-PAGE)}

For SDS-PAGE gel electrophoresis, $15 \mu \mathrm{g}$ total protein of each sample were mixed with the SDS-PAGE buffer containing 2-mercaptoethanol, and applied to a 5-20\% gradient PAGE gel $\left(10 \times 10 \mathrm{~cm}^{2}\right.$ SuperSep pre-cast gel; Wako Jyunyaku) with molecular weight markers, Precision Plus (Bio-Rad Lab.). The electrophoresis was carried out at a constant current of $20 \mathrm{~mA}$. The gel was fixed and stained with $45 \%$ methanol and $10 \%$ acetic acid containing $0 \cdot 2 \%$ Coomassie Brilliant Blue, followed by de-staining with 7\% methanol and $7 \%$ acetic acid.

For 2D-gel electrophoresis, 1D isoelectric focusing with immobilized $\mathrm{pH}$ gradients was performed with Immobiline

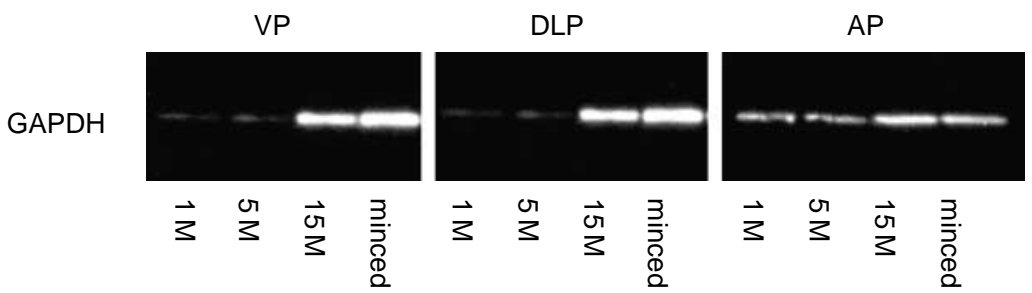

Figure 1 Intracellular contamination in secretion samples. Each prostatic lobe was cut into four or five pieces, and secretion out of the prostatic canals was allowed for 1, 5, and $15 \mathrm{~min}$. Then the lobes were centrifuged and the supernatant was collected as the secretion sample. The samples were applied to the SDS-PAGE (5-20\%) at $0 \cdot 3 \mu \mathrm{g}$ protein/lane, transferred to a piece of PVDF membrane and immunostained with antibody to GAPDH, an inner cellular marker (36 kDa band). The intracellular contamination was lesser in the samples incubated for 1 and $5 \min (1,5 \mathrm{M})$ than in those incubated for $15 \mathrm{~min}(15 \mathrm{M})$ or prepared from minced tissues (minced). The incubation time of $5 \mathrm{~min}$ was chosen for sample preparation in the present study. 
DryStrip (Amersham) and the Ettan IPGphor system (Amersham) according to the manufacturer's protocol. For analytical 2D-PAGE, $10 \mu \mathrm{g}$ de-glycosidated protein was applied in a $7 \mathrm{~cm}$ Immobiline DryStrip (pI 3-11, nonlinear gradient). After rehydration, the strip was isoelectrofocused $(15 \mathrm{kVh})$. The Immobiline gel was then treated with SDS equilibration buffer $(50 \mathrm{mM}$ Tris- $\mathrm{HCl}, \mathrm{pH} 8 \cdot 8,6 \mathrm{M}$ urea, 30\% glycerol, and $2 \%$ SDS) containing $10 \mathrm{mg} / \mathrm{ml}$ DTT for $15 \mathrm{~min}$, followed by the same buffer containing $25 \mathrm{mg} / \mathrm{ml}$ iodoacetamide. The Immobiline gel was then placed on the second SDSPAGE slab gel with 5-20\% gradient (SuperSep pre-cast gel, Wako Jyunyaku) and overlaid with hot agarose solution to connect the two gels. The second electrophoresis was run at a constant current of $20 \mathrm{~mA}$. The gel was fixed with $50 \%$ methanol and 7\% acetic acid, stained overnight in Sypro Ruby (Invitrogen), and de-stained with 10\% methanol and 7\% acetic acid. Stained gels were scanned with a Molecular Imager FX Pro (Bio-Rad Lab.), with excitation at $532 \mathrm{~nm}$. In the case of preparative 2D-PAGE for mass spectrometric analysis, $60 \mu \mathrm{g}$ total protein were subjected to electrophoresis as described previously and then stained with silver nitrate by incubation with $0 \cdot 2 \mathrm{~g} / 1 \mathrm{Na}_{2} \mathrm{~S}_{2} \mathrm{O}_{3}$ for $1 \mathrm{~min}$ followed by $1 \mathrm{~g} / 1 \mathrm{AgNO}_{3}$ for $20 \mathrm{~min}$ on ice, and washed with $20 \mathrm{~g} / 1 \mathrm{Na}_{2} \mathrm{CO}_{3}$ containing 0.1\% HCHO. A 24 cm Immobiline DryStrip (pI, 3-11) was also used for preparation. It was rehydrated with $200 \mu \mathrm{g}$ secreted protein and isoelectrofocused $(25 \mathrm{kVh})$, then placed on $12.5 \%$ SDS-PAGE gel and overlaid with hot agarose solution. The electrophoresis was performed at a constant current of $400 \mathrm{~mA}$. The gel was stained with silver nitrate as described earlier. Three sets of secretion samples from different animals were applied to 2D-electrophoresis and analyzed.

\section{Western blotting}

Total proteins, $0.3 \mu \mathrm{g}$ of each preparation of prostate secretion, were applied to SDS-PAGE (5-20\% gel). Proteins were then transferred to a piece of Hybond-P polyvinylidene difluoride (PVDF) membrane (Amersham). The membrane was incubated with a monoclonal antibody to GAPDH (Ambion) at $1 \mu \mathrm{g} / \mathrm{ml}$ followed by a peroxidaseconjugated antibody to mouse IgG (MBL Co., Nagoya, Japan) at a dilution of 1:1000. Protein bands were detected using the ECL system (Amersham).

\section{Mass spectrometry (MS)}

The protein spots were excised from the polyacrylamide gel and silver nitrate was removed with $15 \mathrm{mM} \mathrm{K}_{3}\left[\mathrm{Fe}(\mathrm{CN})_{6}\right]$ and $50 \mathrm{mM} \mathrm{Na} \mathrm{S}_{2} \mathrm{O}_{3}$. The gel pieces were incubated in distilled water for $1 \mathrm{~h}$, incubated with $\mathrm{CH}_{3} \mathrm{CN}$ for $10 \mathrm{~min}$, and dried in a centrifuge-vacuum concentration system. Each gel piece was incubated with a $20 \mu \mathrm{l}$ aliquot of $10 \mu \mathrm{g} / \mathrm{ml}$ trypsin solution (sequence grade, Sigma) for $30 \mathrm{~min}$ on ice. Excess trypsin solution was removed, and the gel piece was incubated overnight at $35^{\circ} \mathrm{C}$. To extract the digested peptides, $10 \mu \mathrm{l}$ of $70 \% \mathrm{CH}_{3} \mathrm{CN}$ containing $0 \cdot 1 \%$ trifluoroacetic acid were added to each gel piece. An aliquot of $0 \cdot 5 \mu \mathrm{l}$ of the extract solution was spotted onto a target plate for an UltraFlex mass spectrometer (Bruker Daltonics, Bremen, Germany) along with $0.5 \mu \mathrm{l}$ of $10 \mathrm{mg} / \mathrm{ml} \boldsymbol{\alpha}$-cyano-4-hydroxycinnamic acid (MS grade, Nacalai tesque Co., Kyoto, Japan). MS was performed using an accelerating voltage of $20 \mathrm{kV}$, with data acquisition between 1000 and $4000 \mathrm{Da}$. Some of the fragment peaks were further analyzed by MS/MS. The MS and MS/MS data were evaluated with Biotools software (Bruker Daltonics) in combination with a peptide mass fingerprinting analysis system, MASCOT version 2.1 (Matrix Science, London, UK). The peptide mass fingerprinting was performed based on mass spectroscopy protein sequence database (MSDB; Imperial College London, UK) and the nr database at the National Centre for Biotechnology Information (NCBInr; Bethesda, MD, USA) with terminal modifications of peptides set as fixed carbamidomethyl and flexible oxidation ends. The peptide mass tolerance was set to $0 \cdot 3 \%$.

\section{Quantification of $m R N A$ s by real-time RT-PCR}

Total RNA was prepared from each lobe of the prostate with an RNA Isolation kit (Promega), and $2 \mu \mathrm{g}$ total RNA were reverse transcribed as described previously (Fujimoto et al. 2004). An ABI Prism 7700 (Perkin-Elmer Life Sciences, Boston, MA, USA) was employed for quantitative measurement of cDNA using a QuantiTect Sybr Green PCR kit (Qiagen). Specific primer sets with a $T_{\mathrm{m}}$ of about $59{ }^{\circ} \mathrm{C}$ were designed for each mRNA (Table 1). Prior to quantitative analysis, PCR products were prepared separately and purified by gel electrophoresis. The DNA sequences were confirmed with a capillary DNA sequencer, ABI 310 (Perkin-Elmer Life Sciences). Extracted fragments were used as standards for quantification. The PCR conditions were $15 \mathrm{~min}$ of initial activation followed by 45 cycles of $20 \mathrm{~s}$ at $94{ }^{\circ} \mathrm{C}, 30 \mathrm{~s}$ at $58^{\circ} \mathrm{C}$, and $40 \mathrm{~s}$ at $72^{\circ} \mathrm{C}$. All mRNA contents were normalized with reference to $\beta$-actin mRNA.

\section{Serum testosterone levels}

Serum testosterone levels were measured with an ELISA kit, purchased from Neogen Corp. (Lexington, KY, USA).

\section{Statistical analysis}

Statistical comparisons were made using Student's $t$-test.

\section{Results}

\section{D-PAGE analysis}

The secretory proteins from the VP, DLP, AP, and SV were treated with a de-glycosidation enzyme, PNGase F, and analyzed with SDS-PAGE (Fig. 2). In the VP, a broad band at 20-25 kDa was evidently the major band, and a $10 \mathrm{kDa}$ band 
Table 1 Quantitative PCR primers for mouse genes

\begin{tabular}{|c|c|c|c|}
\hline \multirow[b]{2}{*}{ Genes } & GenBank accession \# & $5^{\prime}$-Primer $\left(5^{\prime} \rightarrow 3^{\prime}\right)$ & \multirow[t]{2}{*}{$3^{\prime}$-Primer $\left(5^{\prime} \rightarrow 3^{\prime}\right)$} \\
\hline & & & \\
\hline $91 \mathrm{kDa}$ protein & AK035662 & GGACCTTCCACAAGCGAACAT & GCACTCСTCСAGGTGTTCСTC \\
\hline AGR2 & M_011783 & TTCATCACTTGGACGAATGCC & ACGTACTGGCCATCAGGAGAA \\
\hline Calr & NM_o07591 & ACCGTGAAGCATGAGCAGAAT & TGTTGATCAGCACATTCTTGCC \\
\hline EAPA2 & AY528666 & CCAGACAGGCAGAATTGGGTT & CTCCTCGGAATCTATATTGGCG \\
\hline GRP78 & NM_022310 & TCTTGCCATTCAAGGTGGTTG & TTCTTTCCCAAATACGCСTCAG \\
\hline IgBPLP & XM_620455 & CTGTGAGTTGCCCGAGCCT & CACAATGGAGAACGCСТCСТ \\
\hline PDI & MUSPDIA & CGCAACAACTTTGAGGGTGA & TTGGGCAGGAACAGCAGAAT \\
\hline PLC $\alpha$ & M73329 & ATTGCACTGCCAACACAAACA & АACTGAAGCTGGTCСТGСТTG \\
\hline $\operatorname{Prd} 66$ & BC013489 & AGGACGCTAACAACATGCСТG & GTGCCTGTCAGCTGGAGAGAG \\
\hline Probasin & AF005204 & ACACTGCATGTGCTAGGCGT & TCССАCACAAAATGTGACGG \\
\hline PSP94 & U89840 & CCAACGCTACTAGGCСTTTGA & GCCCACACGAAGCACATTTAC \\
\hline SBP & NM_011321 & TGGAACCCGGTCAGATAACTTT & TCGАССССТТСТААСАССААA \\
\hline SPI-KT3 & ВС086887 & AGAGGCTAGTTGCCATGATGC & GGACAGGCTCTATGCGTTTCC \\
\hline SVS2 & NM_009300 & CAGAGCAGCTССТCAGAGGG & TCTGGGTCATGTCACCACCA \\
\hline $\mathrm{ZnG}$ & AF281658 & СССАСАGGACATAGACСССТТ & CTCATGTCAGGCAGAGAGGGTA \\
\hline$\beta$-Actin & X03765 & CTGTCCCTGTATGCCTCTGGTC & TGAGGTAGTCCGTCAGGTCCC \\
\hline
\end{tabular}

seemed to be secondary. PNGase F treatment shifted the major band to a sharper $19 \mathrm{kDa}$ band, while other bands were unaffected. The main band in the DLP appeared to be a broad band at $80-100 \mathrm{kDa}$, together with bands at 17 and $13 \mathrm{kDa}$.
PNGase $\mathrm{F}$ digested the major band into two sharper bands of approximately 80 and $90 \mathrm{kDa}$, which showed lower staining intensities. The mobility of other bands was not changed much by PNGase F treatment, although some smear-like

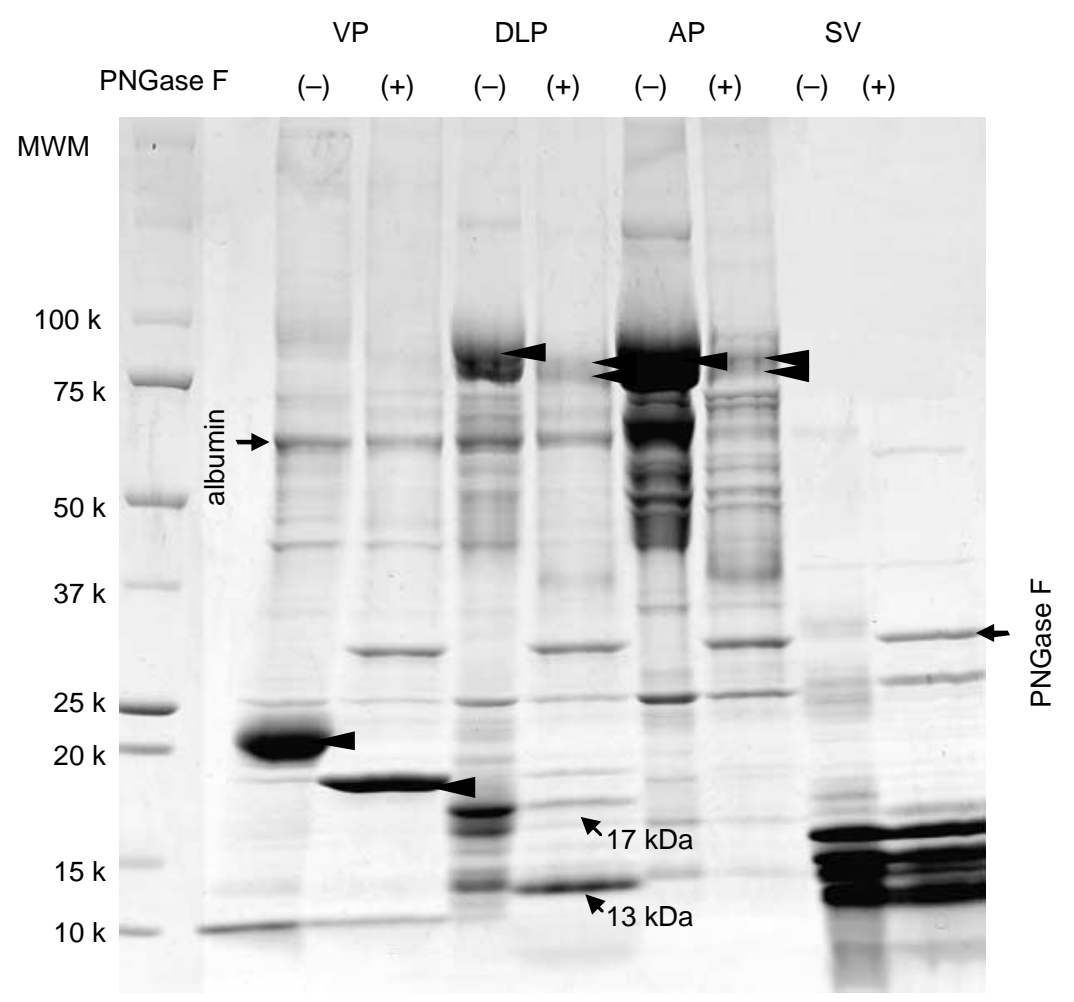

Figure 2 1D-SDS-PAGE analysis of mouse prostate secretory proteins. Secretion was prepared from the VP, DLP, and AP, as well as the SV. Each sample was incubated with $(+)$ or without (-) PNGase F and applied to a 5-20\% gradient SDS-PAGE gel. The gel was stained with Coomassie Brilliant Blue. Arrows indicate major shifted bands by PNGase. 
staining disappeared. When the AP was compared with the DLP, the patterns of bands larger than $25 \mathrm{kDa}$ were similar, as was the effect of PNGase digestion. However, several DLPspecific bands were present in the molecular weight range below $25 \mathrm{kDa}$. A band of albumin, $68 \mathrm{kDa}$, representing contamination from serum, was present in the preparations of prostatic secretion, especially in the VP and DLP. The pattern of SV protein bands was completely different from those of prostatic proteins. The major SV bands were observed between 10 and $16 \mathrm{kDa}$.

\section{D-PAGE and identified proteins}

Secretory proteins from all the lobes were treated with PNGase F and subjected to 2D-PAGE analysis. Owing to the limitation in the pore size of the immobilized $\mathrm{pH}$ gradient gel for isoelectric focusing, proteins with a molecular mass of over $100 \mathrm{kDa}$ could not be analyzed in the 2D-PAGE. Gels were stained and the major spots were picked up for MS analysis (Fig. 3). The analysis of three sets of prostate secretions from independent control mice provided identical patterns. The spots were successfully identified and the results were summarized in Table 2. SBP and SPI-KT3 were major proteins in the VP. In addition, a $91 \mathrm{kDa}$ protein, predicted from urinary bladder cDNA data (AK035662) was identified in the VP, along with glucose-regulated protein 78 (GRP78 or heat-shock $70 \mathrm{kDa}$ protein 5$)$ and peroxiredoxin $6(\operatorname{Prdx} 6)$. Two higher molecular weight proteins in the DLP and AP were identified as experimental autoimmune prostatitis antigen 2 (EAPA2) and a predicted protein similar to immunoglobulinbinding protein (immunoglobulin binding protein-like protein; IgBPLP). Zn- $\alpha 2$-glycoprotein (ZnG), a mammalian homologue of Xenopus anterior gradient 2 (AGR2), as well as PSP94 and probasin, were detected in the DLP secretion. Phospholipase $\mathrm{C} \alpha$ (PLC $\alpha$ ), calreticulin (Calr), and protein disulfide isomerase were also identified in both DLP and AP secretions. SVS2, 4, 5, and 6 were identified in the SV fluid.
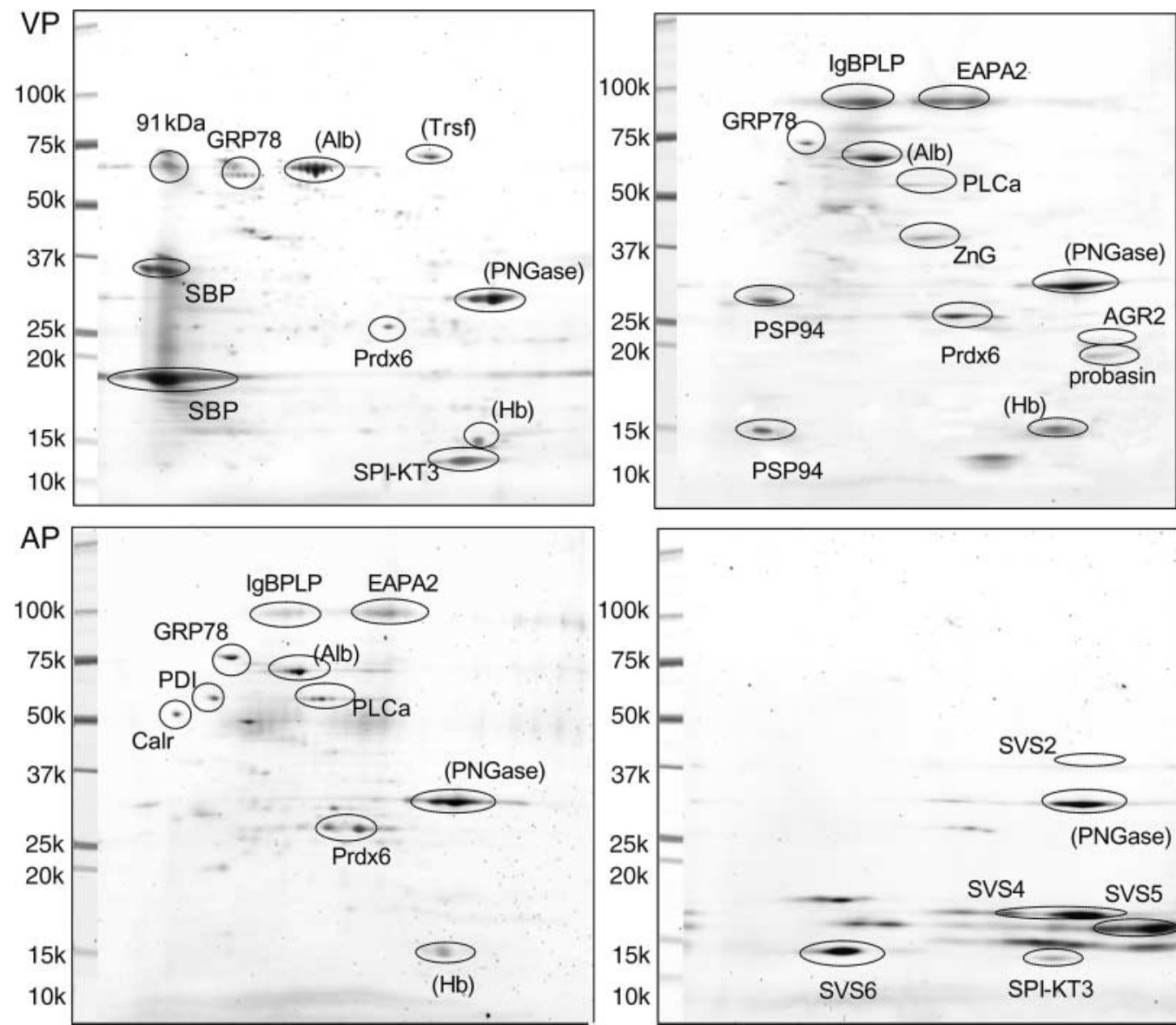

\section{SV}

Figure 3 2D-PAGE analysis of mouse prostate secretory proteins. Each sample from the VP, DLP, AP, and SV was treated with PNGase F and applied to an immobilized $\mathrm{pH}$ gradient gel, followed by a second SDS-PAGE. Gels were stained with Sypro Ruby. The identified spots are indicated in the figure. Serum albumin (Alb), transferrin (Trsf), and hemoglobin $(\mathrm{Hb})$ were considered to be due to serum contamination. 
Table 2 Identified mouse prostatic secretory proteins

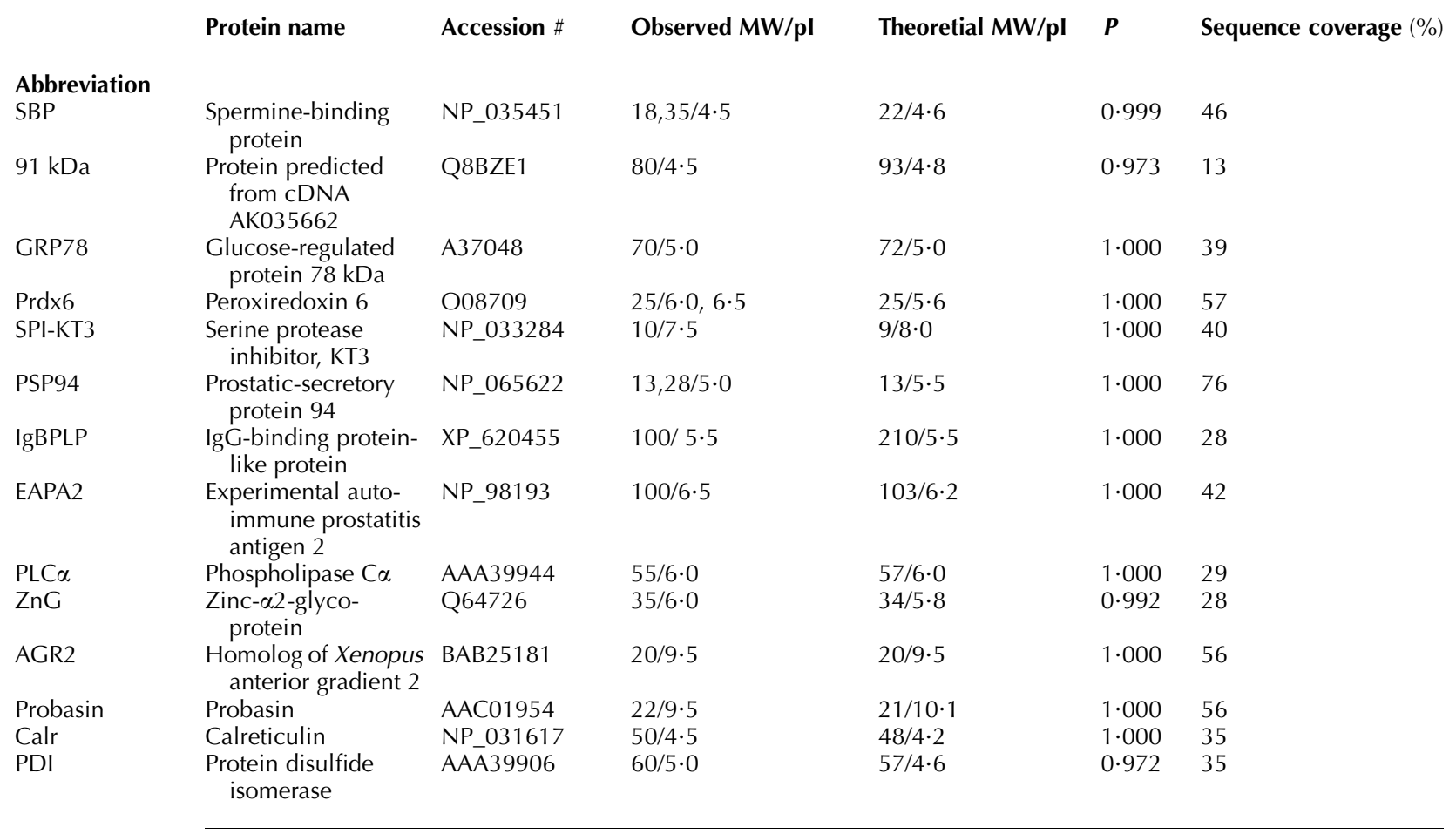

Lobe-specific $m R N A$ expression of identified secreted proteins

Expression of identified proteins in the prostate was further confirmed by examining the mRNA levels; the results are summarized in Table 3. Lobe-specific expression of secreted proteins was evident. Both SBP and SPI-KT3 mRNAs were extremely abundant in the VP but virtually undetectable in the other lobes. The mRNA expression of the $91 \mathrm{kDa}$ protein was also VP-specific. Abundant expression of IgGBPLP and EAPA2 mRNA was detected in the DLP and AP. Probasin expression was specific to the DLP/AP, while PSP94 mRNA was specific to the VP/DLP. The level of $\mathrm{ZnG}$ mRNA was highest in the DLP. The other protein mRNAs were expressed uniformly among the prostatic lobes.

Androgen dependency in $m R N A$ expression of identified secreted proteins

Transcriptional regulation of identified proteins by androgen was examined by comparing mRNA levels among castrated, castrated plus testosterone-treated, and intact animals (Table 4). Serum

Table 3 mRNA levels of identified proteins in each prostatic lobe in 11-week-old mice

\begin{tabular}{|c|c|c|c|c|c|c|c|}
\hline & SBP & SPIKT3 & 91 kDa & PSP94 & ZnG & GRP78 & AGR2 \\
\hline VP & $511 \pm 58 \cdot 9$ & $184 \pm 36 \cdot 0$ & $3 \cdot 6 \pm 0 \cdot 8$ & $2 \cdot 6 \pm 0 \cdot 6$ & $0.9 \pm 0 \cdot 1$ & $1 \cdot 7 \pm 0 \cdot 5$ & $0 \cdot 14 \pm 0 \cdot 03$ \\
\hline DLP & 0 & 0 & $\overline{0}$ & $5 \cdot 8 \pm 1 \cdot 5$ & $12 \cdot 3 \pm 1 \cdot 1$ & $6 \cdot 1 \pm 1 \cdot 7$ & $0 \cdot 38 \pm 0.04$ \\
\hline \multirow[t]{2}{*}{$\mathrm{AP}$} & 0 & 0 & 0 & 0 & $1 \cdot 4 \pm 0 \cdot 3$ & $2 \cdot 7 \pm 0 \cdot 2$ & $0 \cdot 54 \pm 0 \cdot 04$ \\
\hline & PLCa & Calr & PDI & Prdx6 & Probasin & EAPA2 & IgBPLP \\
\hline VP & $0 \cdot 17 \pm 0 \cdot 021$ & $0 \cdot 7 \pm 0 \cdot 1$ & $15 \cdot 0 \pm 2 \cdot 1$ & $2 \cdot 5 \pm 0 \cdot 3$ & $0 \cdot 06 \pm 0 \cdot 02$ & 0 & $0 \cdot 0 \pm 0 \cdot 0$ \\
\hline DLP & $0.36 \pm 0.085$ & $1 \cdot 2 \pm 0 \cdot 3$ & $8 \cdot 3 \pm 2 \cdot 1$ & $21 \cdot 7 \pm 2 \cdot 6$ & $2 \cdot 15 \pm 0 \cdot 23$ & $18 \cdot 9 \pm 1 \cdot 5$ & $67 \cdot 9 \pm 10 \cdot 3$ \\
\hline $\mathrm{AP}$ & $0 \cdot 60 \pm 0.088$ & $1 \cdot 1 \pm 0 \cdot 3$ & $4 \cdot 0 \pm 0 \cdot 8$ & $29 \cdot 0 \pm 5 \cdot 6$ & $0 \cdot 78 \pm 0 \cdot 05$ & $5 \cdot 5 \pm 0 \cdot 8$ & $53 \cdot 0 \pm 0 \cdot 3$ \\
\hline
\end{tabular}

Means \pm S.E.M. $(n=5)$. Values are mRNA levels divided by $\beta$-actin mRNA levels ( $\mathrm{mol} / \mathrm{mol} \beta$-actin). 11-week-old male C57BL mice were killed and total RNA was isolated from each prostate lobe. mRNA levels were measured by real-time RT-PCR. 
Table 4 Androgen regulation of mRNA levels of identified proteins

\begin{tabular}{|c|c|c|c|c|c|c|c|}
\hline & SBP & SPIKT3 & $91 \mathrm{kDa}$ & PSP94 & $\mathrm{ZnG}$ & GRP78 & AGR2 \\
\hline \multicolumn{8}{|l|}{$V P$} \\
\hline Cast & $8 \cdot 2 \pm 0 \cdot 91^{\mathrm{a}}$ & $0 \cdot 24 \pm 0 \cdot 08$ & $0.09 \pm 0.02$ & $0 \cdot 011 \pm 0 \cdot 004$ & $0 \cdot 38 \pm 0.032$ & $0.57 \pm 0.36$ & $0 \cdot 03 \pm 0 \cdot 004$ \\
\hline Cast $+\mathrm{T}$ & $48 \pm 7.9(5.9)^{b}$ & $9 \cdot 3 \pm 3 \cdot 2(39)$ & $0 \cdot 8 \pm 0.23(8 \cdot 4)$ & $0 \cdot 4 \pm 0.008$ & $0 \cdot 56 \pm 0.10(1 \cdot 5)$ & $1 \cdot 02 \pm 0 \cdot 14(1 \cdot 8)$ & $0.14 \pm 0.03(4.9)$ \\
\hline Intact & $511 \pm 58 \cdot 9(62)$ & $184 \pm 36(769)$ & $3 \cdot 6 \pm 0 \cdot 79(40)$ & $2 \cdot 6 \pm 0.55(236)$ & $0.92 \pm 0.09(2 \cdot 4)$ & $1 \cdot 7 \pm 0.47(3 \cdot 0)$ & $0 \cdot 12 \pm 0 \cdot 02(4 \cdot 3)$ \\
\hline \multicolumn{8}{|l|}{$D L P$} \\
\hline Cast & - & - & - & $0 \cdot 002 \pm 0 \cdot 001$ & $0.64 \pm 0.11$ & $0 \cdot 55 \pm 0 \cdot 11$ & $0 \cdot 01 \pm 0 \cdot 001$ \\
\hline Cast $+\mathrm{T}$ & - & - & - & $0 \cdot 08 \pm 0 \cdot 046(38)$ & $2 \cdot 0 \pm 0 \cdot 48(3 \cdot 1)$ & $3 \cdot 4 \pm 0 \cdot 73(1 \cdot 8)$ & $0.06 \pm 0.02(6.9)$ \\
\hline Intact & - & - & - & $5 \cdot 8 \pm 1 \cdot 48(2633)$ & $12 \cdot 3 \pm 1 \cdot 1(19)$ & $6 \cdot 1 \pm 1 \cdot 7(11)$ & $0 \cdot 38 \pm 0 \cdot 04(45)$ \\
\hline \multicolumn{8}{|l|}{$A P$} \\
\hline Cast & - & - & - & - & $0.06 \pm 0.01$ & $0.33 \pm 0.59$ & $0 \cdot 01 \pm 0.002$ \\
\hline Cast $+\mathrm{T}$ & - & - & - & - & $0.21 \pm 0.05(3 \cdot 6)$ & $1 \cdot 33 \pm 0 \cdot 19(4 \cdot 1)$ & $0.08 \pm 0.013(9.5)$ \\
\hline \multirow[t]{2}{*}{ Intact } & - & - & - & - & $1 \cdot 4 \pm 0 \cdot 3(24)$ & $2 \cdot 7 \pm 0 \cdot 22(8 \cdot 3)$ & $0 \cdot 54 \pm 0 \cdot 04(64)$ \\
\hline & PLCa & Calr & PDI & Prdx6 & Probasin & EAPA2 & IgBPLP \\
\hline \multicolumn{8}{|l|}{$V P$} \\
\hline Cast & $0 \cdot 14 \pm 0 \cdot 081$ & $0 \cdot 2 \pm 0 \cdot 03$ & $5 \cdot 6 \pm 1 \cdot 2$ & $3 \cdot 7 \pm 0.73$ & - & - & - \\
\hline Cast $+\mathrm{T}$ & $0.23+0.03(1.6)$ & $0 \cdot 7+0 \cdot 1(3 \cdot 3)$ & $11 \cdot 7+2 \cdot 1(2 \cdot 1)$ & $3 \cdot 8+1 \cdot 41(1 \cdot 0)$ & - & _- & _- \\
\hline Intact & $0 \cdot 17 \pm 0 \cdot 021(1 \cdot 2)$ & $0 \cdot 7+0.09(3 \cdot 5)$ & $15 \cdot 0 \pm 2 \cdot 1(2 \cdot 7)$ & $2 \cdot 5 \pm 0 \cdot 3(0 \cdot 7)$ & - & - & - \\
\hline \multicolumn{8}{|l|}{$D L P$} \\
\hline Cast & $0 \cdot 09 \pm 0 \cdot 014$ & $0 \cdot 2 \pm 0 \cdot 05$ & $1 \cdot 7 \pm 0 \cdot 32$ & $1 \cdot 5 \pm 0 \cdot 41$ & $0 \cdot 02 \pm 0 \cdot 003$ & $0 \cdot 19 \pm 0 \cdot 072$ & $1 \cdot 2 \pm 0 \cdot 29$ \\
\hline Cast $+\mathrm{T}$ & $0.15 \pm 0.02(1.7)$ & $0.3+0.07(1.5)$ & $4 \cdot 5 \pm 1 \cdot 0(2 \cdot 7)$ & $2 \cdot 1 \pm 0 \cdot 22(1 \cdot 4)$ & $0.05 \pm 0.002(2.3)$ & $2 \cdot 4 \pm 0 \cdot 55(13)$ & $1 \cdot 6 \pm 0.6(1.4)$ \\
\hline Intact & $0 \cdot 36 \pm 0 \cdot 085(4 \cdot 0)$ & $1 \cdot 2+0 \cdot 3(6 \cdot 4)$ & $8 \cdot 3 \pm 2 \cdot 1(5 \cdot 0)$ & $21 \cdot 7 \pm 2 \cdot 6(14)$ & $2 \cdot 2 \pm 0 \cdot 23(124)$ & $18 \cdot 9 \pm 1 \cdot 5(102)$ & $67 \cdot 9 \pm 10 \cdot 3(58)$ \\
\hline \multicolumn{8}{|l|}{$A P$} \\
\hline Cast & $0 \cdot 20 \pm 0.03$ & $0.4 \pm 0.06$ & $1 \cdot 4 \pm 0 \cdot 3$ & $1 \cdot 2 \pm 0 \cdot 15$ & $0 \cdot 02 \pm 0 \cdot 004$ & $0 \cdot 17 \pm 0 \cdot 52$ & $0 \cdot 25 \pm 0 \cdot 18$ \\
\hline Cast $+\mathrm{T}$ & $0 \cdot 34 \pm 0.085(1 \cdot 7)$ & $0 \cdot 7 \pm 0.05(1 \cdot 8)$ & $2 \cdot 8 \pm 0 \cdot 5(2 \cdot 0)$ & $4.7 \pm 0.93(4.0)$ & $0 \cdot 04 \pm 0.008(2 \cdot 6)$ & $4 \cdot 8 \pm 0 \cdot 9(29)$ & $1 \cdot 1 \pm 0 \cdot 8(4 \cdot 4)$ \\
\hline Intact & $0 \cdot 60 \pm 0.088(3 \cdot 0)$ & $1 \cdot 1 \pm 0 \cdot 3(2 \cdot 8)$ & $4 \cdot 0 \pm 0 \cdot 8(2 \cdot 8)$ & $29 \cdot 0 \pm 5 \cdot 6(25)$ & $0 \cdot 78 \pm 0 \cdot 051(49)$ & $5 \cdot 5 \pm 0 \cdot 8(33)$ & $53 \cdot 0 \pm 0 \cdot 31(215)$ \\
\hline
\end{tabular}

${ }^{a}$ Mean \pm S.E.M. $(n=5)$. Values are mRNA levels divided by $\beta$-actin mRNA levels ( $\mathrm{mol} / \mathrm{mol} \beta$-actin).
bValues in parenthesis are fold change in mRNA over the castrated.10-week-old male C57BL mice were castrated and maintained for a week (cast). They were killed $24 \mathrm{~h}$ after testosterone administration at $5 \mathrm{mg} / \mathrm{kg}$ bw, ip (Cast $+\mathrm{T})$. Total RNA was isolated from each prostate lobe and amounts of mRNA were measured by real-time RT-PCR. 
testosterone levels were $0,5 \cdot 2 \pm 0 \cdot 15$, and $1 \cdot 5 \pm 0 \cdot 15 \mathrm{ng} / \mathrm{ml}$ in castrated, castrated plus testosterone injected, and intact groups respectively. Serum testosterone levels reached $38 \mathrm{ng} / \mathrm{ml}, 1 \mathrm{~h}$ after a testosterone injection. The mRNA levels of identified secreted proteins decreased 1 week after castration, although the extent of the decrease differed among protein species. For instance, SPI-KT3 mRNA in the VP was greatly decreased in castrated animals to only $1 / 769$ of the intact control level, while castration reduced SBP expression to $1 / 62$ of the control. The extent of change in mRNA expression also varied between lobes. GRP78 mRNA in the DLP, for instance, was decreased to $1 / 11$ of the control by castration but only to about $1 / 3$ of the control in the VP. The mRNA levels were normalized by $\beta$-actin levels, which were not affected by castration and testosterone treatment. The $\beta$-actin levels in the VP were $3 \cdot 5 \pm 0 \cdot 36,3 \cdot 8 \pm 0 \cdot 30$, and $3 \cdot 5 \pm 0.34 \mathrm{fg} / \mathrm{ng}$ total RNA in the castrated, the castrated plus testosterone and intact groups respectively. The values were $4 \cdot 8 \pm 0 \cdot 74,5 \cdot 3 \pm 0 \cdot 99$, and $4 \cdot 3 \pm 0 \cdot 40$ for the DLP, and $3 \cdot 9 \pm 0 \cdot 24,4 \cdot 2 \pm 0 \cdot 60$, and $4 \cdot 7 \pm 0 \cdot 26$ for the AP.

\section{Ontogeny in $m R N A$ expression of identified secreted proteins}

The expression of identified secreted protein mRNAs was examined in each lobe of the prostate at ages 1, 2, 4, 6, and 11 weeks (Table 5). Low levels of mRNA expression were noted at 1 week. Significant increases of SBP and EAPA2 mRNAs began at 2 weeks and continued thereafter. Increases in other secretory protein mRNAs, including $91 \mathrm{kDa}$ protein, PSP94 and IgGBPLP mRNAs, were apparent at 4 weeks.

\section{Discussion}

In the present study, the major secretory proteins of the mouse VP, DLP, and AP were identified by mass spectrometric analysis after 2D-gel electrophoresis (Table 6). IgBPLP and EAPA2 were major proteins in the DLP/AP. A $91 \mathrm{kDa}$ protein predicted from a mouse urinary bladder cDNA (AK035662), Prdx6 and PLC $\alpha$ were also found in the prostatic secretion for the first time, in addition to previously reported prostatic proteins, including SBP (Mills et al. 1987b), SPI-KT3 (Mills et al. 1987a), PSP94 (Xuan et al. 1999), and probasin (Johnson et al. 2000). The mRNAs for these proteins were expressed in a lobe-specific manner and were regulated by androgen. Our study has delineated the main mouse prostatic secretion pattern for the first time. The data will be useful for studying androgen-dependent gene regulation in the prostate, and may also provide markers for studying functional differentiation of prostate tissue.

Production and secretion of prostatic proteins are the main physiological functions of the prostate gland. Prostatic secretory proteins have been studied in rats as well as in humans, especially from the viewpoint of androgen-dependent regulation of expression and to identify possible markers of prostate cancer. The major human prostatic-secreted proteins are PSA (prostate-specific antigen), PSP94, and prostatic acid phosphatase (Lee et al. 1986). In rat, the composition of prostatic proteins is different; only PSP94 is common with the human case, and the production of each protein varies among lobes. In the VP, prostatic-binding protein or prostatein is the major secreted protein, while cystatin-related protein and kallikreins are also produced abundantly (Heyns 1990). The LP and DP secrete probasin,

Table 5 Ontogeny of mRNA levels of identified proteins in the prostate

\begin{tabular}{|c|c|c|c|c|c|}
\hline & SBP & $91 \mathrm{~K}$ & PSP94 & EAPA2 & IgBPLP \\
\hline \multicolumn{6}{|l|}{$V P$} \\
\hline $1 \mathrm{~W}$ & $0 \cdot 1 \pm 0 \cdot 04$ & $0 \cdot 1 \pm 0 \cdot 02$ & $0 \cdot 1 \pm 0 \cdot 05$ & - & - \\
\hline $2 W$ & $17 \cdot 9 \pm 3 \cdot 8^{*}$ & $0 \cdot 1 \pm 0 \cdot 01$ & $0 \cdot 2 \pm 0 \cdot 08$ & - & - \\
\hline $4 W$ & $78 \cdot 5 \pm 15 \cdot 3 *$ & $0 \cdot 8 \pm 0 \cdot 07^{+}$ & $2 \cdot 6 \pm 0 \cdot 23^{+}$ & - & - \\
\hline $6 W$ & $503 \cdot 0 \pm 106^{*}$ & $3 \cdot 6 \pm 0.23^{+}$ & $16 \cdot 0 \pm 3 \cdot 9^{+}$ & - & - \\
\hline $11 \mathrm{~W}$ & $474.9 \pm 77 \cdot 3^{*}$ & $4 \cdot 4 \pm 0 \cdot 50^{+}$ & $4 \cdot 2 \pm 0.6^{+}$ & - & - \\
\hline \multicolumn{6}{|l|}{$D L P$} \\
\hline $1 \mathrm{~W}$ & - & - & $0 \cdot 0 \pm 0 \cdot 03$ & $0 \cdot 18 \pm 0 \cdot 06$ & $0 \cdot 05 \pm 0 \cdot 02$ \\
\hline $2 W$ & - & - & $0 \cdot 0 \pm 0 \cdot 01$ & $0.42 \pm 0.06^{*}$ & $0.09 \pm 0.02$ \\
\hline $4 W$ & - & - & $1 \cdot 1 \pm 0 \cdot 32 *$ & $0 \cdot 88 \pm 0.27$ & $0 \cdot 68 \pm 0.21$ \\
\hline $6 W$ & - & - & $12 \cdot 7 \pm 1 \cdot 5^{\dagger}$ & $3.95 \pm 0.79 *$ & $7 \cdot 43 \pm 1 \cdot 5^{*}$ \\
\hline $11 \mathrm{~W}$ & - & - & $4 \cdot 0 \pm 0 \cdot 2^{\dagger}$ & $15 \cdot 3 \pm 2 \cdot 36^{+}$ & $102 \pm 22 \cdot 0^{\dagger}$ \\
\hline \multicolumn{6}{|l|}{$A P$} \\
\hline $1 \mathrm{~W}$ & - & - & - & $0 \cdot 18 \pm 0 \cdot 04$ & $0 \cdot 04 \pm 0 \cdot 01$ \\
\hline $2 W$ & - & - & - & $0.74 \pm 0.02 *$ & $0 \cdot 1 \pm 0.02$ \\
\hline $4 W$ & - & - & - & $1 \cdot 10 \pm 0 \cdot 4$ & $1 \cdot 9 \pm 0.26^{\dagger}$ \\
\hline $6 W$ & - & - & - & $3.55 \pm 0.53^{t}$ & $30 \cdot 1 \pm 3 \cdot 6^{+}$ \\
\hline $11 \mathrm{~W}$ & - & - & - & $5 \cdot 50 \pm 0 \cdot 80^{\dagger}$ & $53 \cdot 2 \pm 8 \cdot 1^{+}$ \\
\hline
\end{tabular}

Means \pm s.E.M. $(n=4)$. Values are mRNA levels divided by $\beta$-actin mRNA levels (mol/mol $\beta$-actin) 1, 2, 4, 6 and 11 -week-old $(\mathrm{W}) \mathrm{male}$ C57BL mice were killed. Total RNA was isolated from each prostate lobe and amounts of mRNA were measured by real-time RT-PCR. $* P<0.05$ and ${ }^{\dagger} P<0.01$ vs. $1 \mathrm{~W}$. 
Table 6 Summary: identified mouse prostatic secretory proteins

\section{Lobe specificity

castration
case by

$\begin{array}{ll}\text { VP } & ++ \\ \text { VP, (SV) } & +++ \\ \text { VP } & ++ \\ \text { VP, DLP } & +++ \\ \text { DLP }>\text { VP, AP } & + \\ \text { VP, DLP, AP } & + \\ \text { VP, DLP, AP } & + \\ \text { VP, DLP, AP } & + \\ \text { VP, DLP, AP } & + \\ \text { VP, DLP, AP } & + \\ \text { DLP, AP > VP } & ++ \\ \text { DLP, AP } & +++ \\ \text { DLP, AP } & +++ \\ \text { DLP, AP } & +++\end{array}$

\section{Description}

Known prostatic protein (Mills et al. 1987b)

Known prostatic protein (Mills et al. 1987a)

Scavenger receptor cys-rich (SRCR) domains

Known prostatic protein (Xuan et al. 1999)

Ribonuclease activity?

Heat-shock protein 70 family

Human homolog expressed in prostatic cancer cell lines

Enzyme involved in phosphatidylinositol metabolism

Calcium-binding protein

Enzyme involved in protein folding

Antioxidant protein

Known prostatic protein (Johnson et al. 2002)

No homology with any known protein

IgG binding? Willebrand factor D domains, trypsin inhibitor like
PSP94, and SVS2 (Imasato et al. 2001). A kinesin heavy chainlike protein and an IgG-binding protein were recently reported in the secretion of the AP (Esposito et al. 2001, Wilhelm et al. 2002).

In spite of the morphological similarity of the prostate in mouse and rat, previous studies have suggested a substantial difference in prostatic secretion between the two species (Donjacour et al. 1990). Since mouse prostatic proteins are known to be highly glycosylated, we first examined the effects of glycosidase digestion on prostatic proteins. Endo $\mathrm{H}$ glycosidase, which cleaves mainly within the chitobiose core of high mannose, did not change the SDS-PAGE pattern (data not shown). On the other hand, PNGase F, which removes all types of N-linked glycosylation, changed the pattern. A broad band of SBP in the VP was converted to a sharp band with smaller molecular weight, and smear-like bands between 40 and $100 \mathrm{kDa}$ in the DLP/AP were also converted to sharper bands, indicating that proteins were de-glycosylated by the enzyme. In spite of highly glycosylated characteristics of mouse prostate proteins, the biological role of glycosylation is not yet understood.

In the mouse prostate, only VP-secreted proteins have been investigated, and two major proteins, SBP and SPI-KT3, were identified (Mills et al. 1987a,b). The present study confirmed the secretion of these two proteins and also revealed the presence of other proteins, including $91 \mathrm{kDa}$ protein, Prdx6 and GRP78. The $91 \mathrm{kDa}$ protein is expected to consist of 841 a with two predicted extracellular (CUB) domains and three scavenger receptor cystine-rich (SRCR) domains, and is expressed preferentially in the VP. The size of the protein, however, seems to be less than $91 \mathrm{kDa}$ in the gel. Since the sequence coverage of peptide mass fingerprinting is only $13 \%$, the actual reading frame may be shorter than the predicted one. $\operatorname{Prdx} 6$ is another new component of the prostatic secretion found in the present study. Since it is an antioxidant enzyme that reduces peroxide and alkyl hydroperoxide to water and alcohol respectively (Wang et al. 2003), it may provide seminal plasma antioxidant capability. GRP78 belongs to the heatshock protein 70 family, which had been considered as intercellular proteins. However, a recent proteomic analysis of human prostasomes revealed the presence of heat shock proteins in prostatic secretion (Utleg et al. 2003). In addition, heat-shock protein 70 has been reported to be secreted from a variety of prostatic cell lines, and to show growth-inhibitory activity (Jones et al. 2004, Wang et al. 2004). Secreted mouse GRP78 may have a similar activity.

Although mouse DLP proteins had not been biochemically identified, Cunha's group has recognized 110 and $55 \mathrm{kDa}$ bands in SDS-PAGE as major DLP/AP proteins (Donjacour et al. 1990). They reported that DLP/AP proteins are highly glycosylated, which was confirmed by the present study. The predicted IgGBPLP sequence derived from the cDNA sequence (XM_620455), however, is calculated to contain 1866 a with a molecular mass of $201 \mathrm{kDa}$. Because peptide sequencing by the peptide-mass fingerprinting method covered the whole predicted sequence ( $27 \%$ coverage), the $100 \mathrm{kDa}$ spot probably contains a mixture of cleaved fragments derived from the $201 \mathrm{kDa}$ protein, although this remains to be confirmed. Recently, an IgG-binding protein of $115 \mathrm{kDa}$ was reported to be secreted also from the rat $\mathrm{AP}$, suggesting that a rat homolog exists (Wilhelm et al. 2002). The predicted cDNA sequence corresponding to this rat protein (XM_620455), which became available more recently, encodes $206 \mathrm{kDa}$ protein (1914 aa) instead of $115 \mathrm{kDa}$. There is $84 \%$ similarity between the mouse and the rat sequences. Secretion of EAPA2, which is one of the antigens found in experimental autoimmune prostatitis, is also a noteworthy finding in the present study. This protein of 914 aa contains no known domain structure and has no homology with any known functional protein. Secretion of both PSP94 and probasin was detected in the DLP, as expected, since both proteins are well characterized in rats and have been reported in mice (Xuan 
et al. 1999, Johnson et al. 2000). The other identified DLP proteins include GRP78, Prdx6, ZnG, AGR2, Calr, and protein disulfide isomerase (PDI). Prostatic secretion of $\mathrm{ZnG}$ has been reported in humans, and $\mathrm{ZnG}$ is widely distributed in body fluids and in various epithelia (Lei et al. 1998, Hale et al. 2001). AGR2 is a mammalian homolog of Xenopus AGR2, which was recently reported to be secreted from human prostate under androgen regulation (Zhang et al. 2005). It is overexpressed in prostate cancer and the expression level is correlated with pathological grade. Calr is a highly conserved calcium-binding protein involved in a wide variety of cellular processes (Krause \& Michalak 1997). Interestingly, the Calr gene was identified as an androgeninducible gene in the rat VP (Zhu et al. 1998). PDI is involved in the maintenance of folding of synthesized proteins. Specific expression of PDI in the prostate was recently reported in humans (Lexander et al. 2005). Since both Calr and PDI are considered to be localized in the lumen of endoplasmic reticulum, they may represent contaminants introduced during preparation of the secretion sample. Secretion from the AP is similar to that from the DLP, i.e. the major secretory proteins are IgGBPLP and EAPA2, but little ZnG and no PSP94 are found in the secretion. The results of mass spectrometric identification of SV proteins were generally in agreement with previous reports, i.e. SVS2, 4, 5, and 6, as well as SPI-KT3 (Lai et al. 1991, Lundwall et al. 1997). Except SPI-KT3, SV proteins are specifically expressed in the SV and not in the prostate gland, which differs from the rat case, where SVS2, for instance, is highly expressed in DLP/AP.

Quantitative determination of mRNA expression revealed a clear transcriptional differentiation of secreted proteins among the lobes. The levels of secretory protein mRNAs were very high, ranging from 1 to 500 times that of the housekeeping gene $\beta$-actin, used as an internal control in the present study. The mRNA levels overall correlated with the intensity of protein staining in the gel, although spots of protein with larger molecular weight, such as EAPA2 and IgBPLP show lesser intensity in the 2D-gel, since the 1D-gel used in the present study is only able to hold proteins with molecular weights less than $80-100 \mathrm{kDa}$. Since all the identified secreted proteins decreased significantly a week after castration of the animal, these protein transcripts are androgen-dependent directly or indirectly through involution of the gland. In rats, various studies have shown a faster response of the VP to androgen action, as compared with other lobes. For instance, castration decreased probasin mRNA expression to $1 \%$ of the control level after a week, while the decrease in the DLP was only $50 \%$ (Imasato et al. 2001). In the mouse, however, large decreases in mRNAs were evident in all the lobes. We examined the effect of a single injection of testosterone on the mRNAs in castrated animals to confirm the androgen dependency of transcription. The serum testosterone level well exceeded the control level within $1 \mathrm{~h}$ and was still high $24 \mathrm{~h}$ after an injection. Although most mRNA levels increased significantly after an injection, which clearly demonstrates their androgen inducibility, most of them were not restored to the intact control level. It may suggest that the full activity of androgen-dependent genes in the prostate is involved in both short- and long-term transcriptional regulation mechanisms by androgen.

Although rodent prostate models have been used for investigating the mechanism of prostate carcinogenesis, anatomical differences between rodent and human prostate have led to concerns about the validity of rodents as suitable models for human prostate cancer. Besides, mice are resistant to induction of prostate tumors by chemical carcinogens. However, a number of transgenic or knockout mouse lines have become available in which prostate carcinomas preferentially occur. For instance, the TRAMP transgenic line expresses the SV40 antigen under the control of the rat probasin promoter. The TRAMP mice develop high-grade prostatic intraepithelial neoplasia and prostate cancer within 12 weeks of birth, and ultimately develop metastases to the regional lymph nodes and lung by 30 weeks. In addition, androgen depletion by castration results in decreased tumor incidence. Their futures are similar to the human case, although metastasis to bone, a characteristic feature of human prostate cancer, is rare. The expression pattern of secretion proteins may be related to development of prostate carcinogenesis. Since the present study has revealed mouse prostate secretion, these can now be examined in relation to the development of prostate carcinogenesis as well as androgen-dependent differentiation of the gland. The ontogeny of mRNA expression of secreted proteins indicated that significant expression started 2 weeks after birth, which is consistent with the fact that branching morphogenesis of the mouse prostate is completed in the first 15 days of birth.

The present study has provided an understanding of the major secretory function of the mouse prostate, and identified common aspects of secretory functionality between mouse and human, e.g. for heat-shock proteins, $\mathrm{ZnG}$ and peroxiredoxin. The identified secretory proteins should be available as models of androgen-dependent gene regulation and are candidates as markers for prostatic differentiation. Like human PSA or PSP94, some of the identified proteins may be useful as pathological markers associated with prostate disorders; this would facilitate prostate research in mouse models.

\section{Acknowledgements}

We thank Ms R Tai for her expert technical assistance and Dr $\mathrm{S}$ Izumi for his expert suggestions for mass spectrometry. This work was supported in part by a Grant-in-Aid (H16-Seikatsu) from the Ministry of Health, Labor and Welfare, Japan and a Grant-in-Aid (\#17510046) from the Ministry of Education, Culture, Sports, Science and Technology, Japan. The authors declare that there is no conflict of interest that would prejudice the impartiality of this scientific work. 


\section{References}

Abate-Shen C \& Shen MM 2002 Mouse models of prostate carcinogenesis Trends in Genetics $18 \mathrm{~S} 1-\mathrm{S} 5$.

Cunha GR, Donjacour AA, Cooke PS, Mee S, Bigsby RM, Higgins SJ \& Sugimura Y 1987 The endocrinology and developmental biology of the prostate. Endocrine Reviews 8 338-362.

Donjacour AA, Rosales A, Higgins SJ \& Cunha GR 1990 Characterization of antibodies to androgen-dependent secretory proteins of the mouse dorsolateral prostate. Endocrinology 126 1343-1354.

Esposito C, Mariniello L, Cozzolino A, Amoresano A, Orru S \& Porta R 2001 Rat coagulating gland secretion contains a kinesin heavy chain-like protein acting as a type IV transglutaminase substrate. Biochemistry 40 4966-4971.

Fujimoto N, Igarashi K, Kanno J, Honda H \& Inoue T 2004 Identification of estrogen-responsive genes in the GH3 cell line by cDNA microarray analysis. Journal of Steroid Biochemistry and Molecular Biology 91 121-129.

Greenberg NM, DeMayo F, Finegold MJ, Medina D, Tilley WD, Aspinall JO, Cunha GR, Donjacour AA, Matusik RJ \& Rosen JM 1995 Prostate cancer in a transgenic mouse. PNAS 92 3439-3443.

Hale LP, Price DT, Sanchez LM, Demark-Wahnefried W \& Madden JF 2001 Zinc alpha-2-glycoprotein is expressed by malignant prostatic epithelium and may serve as a potential serum marker for prostate cancer. Clinical Cancer Research 7 846-853.

Heyns W 1990 Androgen-regulated proteins in the rat ventral prostate. Andrologia 22 (Suppl 1) 67-73.

Imasato Y, Onita T, Moussa M, Sakai H, Chan FL, Koropatnick J, Chin JL \& Xuan JW 2001 Rodent PSP94 gene expression is more specific to the dorsolateral prostate and less sensitive to androgen ablation than probasin. Endocrinology 142 2138-2146.

Johnson MA, Hernandez I, Wei Y \& Greenberg N 2000 Isolation and characterization of mouse probasin: an androgen-regulated protein specifically expressed in the differentiated prostate. Prostate 43 255-262.

Jones EL, Zhao MJ, Stevenson MA \& Calderwood SK 2004 The 70 kilodalton heat shock protein is an inhibitor of apoptosis in prostate cancer. International Journal of Hyperthermia 20 835-849.

Klein RD 2005 The use of genetically engineered mouse models of prostate cancer for nutrition and cancer chemoprevention research. Mutation Research 576 111-119.

Krause KH \& Michalak M 1997 Calreticulin. Cell 88 439-443.

Lai ML, Chen SW \& Chen YH 1991 Purification and characterization of a trypsin inhibitor from mouse seminal vesicle secretion. Archives of Biochemistry and Biophysics $290265-271$.

Lee C, Tsai Y, Sensibar J, Oliver L \& Grayhack JT 1986 Two-dimensional characterization of prostatic acid phosphatase, prostatic specific antigen and prostate binding protein in expressed prostatic fluid. Prostate 9 135-146.

Lei G, Arany I, Tyring SK, Brysk H \& Brysk MM 1998 Zinc-alpha 2-glycoprotein has ribonuclease activity. Archives of Biochemistry and Biophysics 355 160-164.

Lexander H, Franzen B, Hirschberg D, Becker S, Hellstrom M, Bergman T, Jornvall H, Auer G \& Egevad L 2005 Differential protein expression in anatomical zones of the prostate. Proteomics 5 2570-2576.

Lundwall A, Peter A, Lovgren J, Lilja H \& Malm J 1997 Chemical characterization of the predominant proteins secreted by mouse seminal vesicles. European Journal of Biochemistry 249 39-44.

Maddison LA, Sutherland BW, Barrios RJ \& Greenberg NM 2004 Conditional deletion of $\mathrm{Rb}$ causes early stage prostate cancer. Cancer Research 64 6018-6025.

McPherson SJ, Wang H, Jones ME, Pedersen J, Iismaa TP, Wreford N, Simpson ER \& Risbridger GP 2001 Elevated androgens and prolactin in aromatase-deficient mice cause enlargement, but not malignancy, of the prostate gland. Endocrinology 142 2458-2467.
Mills JS, Needham M \& Parker MG 1987a A secretory protease inhibitor requires androgens for its expression in male sex accessory tissues but is expressed constitutively in pancreas. EMBO Journal 6 3711-3717.

Mills JS, Needham M \& Parker MG $1987 b$ Androgen regulated expression of a spermine binding protein gene in mouse ventral prostate. Nucleic Acids Research 15 7709-7724.

Omoto Y, Imamov O, Warner M \& Gustafsson JA 2005 Estrogen receptor alpha and imprinting of the neonatal mouse ventral prostate by estrogen. PNAS 102 1484-1489.

Robertson FG, Harris J, Naylor MJ, Oakes SR, Kindblom J, Dillner K, Wennbo H, Tornell J, Kelly PA, Green J et al. 2003 Prostate development and carcinogenesis in prolactin receptor knockout mice. Endocrinology 144 3196-3205.

Shirai T, Takahashi S, Cui L, Futakuchi M, Kato K, Tamano S \& Imaida K 2000 Experimental prostate carcinogenesis - rodent models. Mutation Research 462 219-226.

Utleg AG, Yi EC, Xie T, Shannon P, White JT, Goodlett DR, Hood L \& Lin B 2003 Proteomic analysis of human prostasomes. Prostate 56 150-161.

Wang X, Phelan SA, Forsman-Semb K, Taylor EF, Petros C, Brown A, Lerner CP \& Paigen B 2003 Mice with targeted mutation of peroxiredoxin 6 develop normally but are susceptible to oxidative stress. Journal of Biological Chemistry 278 25179-25190.

Wang MH, Grossmann ME \& Young CY 2004 Forced expression of heatshock protein 70 increases the secretion of $\mathrm{Hsp} 70$ and provides protection against tumour growth. British Journal of Cancer 90 926-931.

Weihua Z, Makela S, Andersson LC, Salmi S, Saji S, Webster JI, Jensen EV, Nilsson S, Warner M \& Gustafsson JA 2001 A role for estrogen receptor beta in the regulation of growth of the ventral prostate. PNAS $\mathbf{9 8}$ $6330-6335$.

Wennbo H, Kindblom J, Isaksson OG \& Tornell J 1997 Transgenic mice overexpressing the prolactin gene develop dramatic enlargement of the prostate gland. Endocrinology 138 4410-4415.

Wilhelm B, Keppler C, Henkeler A, Schilli-Westermann M, Linder D, Aumuller G \& Seitz J 2002 Identification and characterization of an IgG binding protein in the secretion of the rat coagulating gland. Biological Chemistry 383 1959-1965.

Xuan JW, Kwong J, Chan FL, Ricci M, Imasato Y, Sakai H, Fong GH, Panchal C \& Chin JL 1999 cDNA, genomic cloning, and gene expression analysis of mouse PSP94 (prostate secretory protein of 94 amino acids). DNA and Cell Biology 18 11-26.

Zhang JS, Gong A, Cheville JC, Smith DI \& Young CY 2005 AGR2, an androgen-inducible secretory protein overexpressed in prostate cancer. Genes, Chromosomes and Cancer 43 249-259.

Zhu N, Pewitt EB, Cai X, Cohn EB, Lang S, Chen R \& Wang Z 1998 Calreticulin: an intracellular $\mathrm{Ca}^{++}$-binding protein abundantly expressed and regulated by androgen in prostatic epithelial cells. Endocrinology 139 $4337-4344$.

Received 4 January 2006

Received in final form 24 April 2006

Accepted 26 May 2006

Made available online as an Accepted Preprint 13 June 2006 